\title{
Willing Workers on Organic Farms (WWOOF): The Alternative Farm Stay Experience?
}

\author{
Alison J. Mclntosh \\ The University of Waikato, New Zealand
}

\section{Susanne M. Bonnemann}

Lincoln University, New Zealand

This paper aims to contribute to knowledge about the farm stay experience by providing exploratory insights into the characteristics that are common to a hosted stay on a WWOOF farm and to investigate whether the experiences provided for visitors by WWOOF hosts are notably different from those offered by other farm hosts. The paper reports the findings of in-depth interviews conducted with 12 WWOOF hosts and 22 visitors staying at WWOOF farms located in the rural region of Canterbury in the south island of New Zealand. The findings of the study, while indicative, show that the hosted experience on an organic (WWOOF) farm may be notably different from that provided at a commercial farm stay, with four key dimensions: the rurality of the experience; the opportunity to learn about organics; the personal meaningfulness of the experience; and the element of sincerity in the experience.

Keywords: farm tourism, WWOOF, New Zealand, tourist experiences

\section{Introduction}

Farm tourism has become an important factor in the rural economies of many Western countries and serves as an important component in the cultural appeal of rural destinations. Commentators have argued that tourists increasingly seek authenticity in 'the different' which everyday life cannot offer (MacCannell, 1992), such as in the experience of rural lifestyles, or, the 'ordinary life of others in different countries' (Pearce, 1990: 351). Although attention to visitors' experiences at farm stays is important for the achievement of sustainable farm hosting and, more generally, for rural destination development, the published literature on farm tourism has provided minimal analysis of visitors' perspectives of farm tourism. Exceptions to this include McKenzie (1994), Oppermann (1996, 1998) and Pearce (1990). These studies have provided piecemeal information on visitors' motivations, demographic profiles or activities undertaken at farm stays. However, with the exception of Pearce (1990), they did not examine the nature of social interaction between hosts and visitors within the farm stay context.

The hosted farm stay experience has also not been considered in the context of alternative farm types or practices, such as hosting on organic farms, longer-term stays or farms offering special attractions or experiences. The WWOOF (Willing Workers on Organic Farms) network offers some of these alternatives. However, 
McIntosh and Campbell (2001: 111) in their New Zealand study of WWOOF farms have argued that the WWOOF phenomenon is 'a neglected aspect of farm tourism'. They also argued that the facilitation of tourism experiences on the farm remains a concern, generally, among WWOOF hosts. While hosting on organic (WWOOF) farms has, over recent years, seemingly contributed to rural tourism worldwide, there has been very little analysis of this alternative farm tourism experience in the published debates concerning farm tourism (McIntosh \& Campbell, 2001). Furthermore, an analysis of the demographic profile of WWOOFers has not been considered in published sources. The experiences provided for visitors staying on organic (WWOOF) farms in New Zealand from the perspectives of both farm hosts and visitors, and the demographic profiles of visitors to WWOOF farms are the focus of the present paper.

In this paper, the term 'commercial farm stays' means conventional farm accommodation provision, paid for using money, rather than offering services or work in lieu of payment. Normally these stays will be relatively short in duration. The term commercial farm stay may include some farms that employ organic farming techniques. Organic farming entails the restriction of the use of artificial fertilisers, pesticides and herbicides, high standards of animal welfare and husbandry, and the rejection of genetically modified crops (see www. soilassociation.org for further information). Full details of the WWOOF network and WWOOF visitors ('WWOOFers') are given below.

\section{The WWOOF Venture as an Aspect of Farm Tourism}

WWOOF is a membership organisation that offers volunteer workers the opportunity to experience life on an organic farm. WWOOF is a worldwide network of organisations that share a common philosophy to promote the organic movement. Information on the origins and work of the WWOOF organisation is beyond the limits of the present paper and can be readily sourced elsewhere (see e.g. McIntosh \& Campbell, 2001; http:/ / www.wwoof.org). In New Zealand, there were 613 WWOOF hosts listed in the New Zealand WWOOF book in 2001 and approximately 3700 visitors stayed on WWOOF farms. In 2003, these figures had increased to 802 WWOOF hosts and approximately 5850 visitors. The number of WWOOF visitors in 2003 represented a $153 \%$ increase since 1993. A comparison between the number of WWOOF farms and the overall number of commercial farm stays in New Zealand is impossible to estimate because commercial farm tourism enterprises are not centrally registered and have no official directory. Furthermore, commercial farm stays are difficult to identify and define as they are often promoted along with home stays and bed and breakfast accommodation more generally. As such, different statistical sources provide differing estimates of the total number of commercial farm stay enterprises in New Zealand. One source, New Zealand's largest farm stay association, Rural Tourism Holdings, lists approximately 1200 farm stay operators (www.ruraltourism.co.nz). In relation to demand, Warren and Taylor (1999) reported that there are approximately 49,000 international visitors using farmhouse accommodation in a year, accounting for approximately 700,000 visitor nights or about $3 \%$ of all international tourist visitor nights in New Zealand. As such, WWOOF hosts may represent a significant proportion of farm hosts 
overall. However, caution is advised in interpreting this conclusion for the reasons mentioned above.

Unlike commercial farm stays, WWOOF farm hosts are generally not commercially orientated, nor are they involved in commercial advertising. Visitors wishing to stay on a WWOOF farm must first become a member of the WWOOF organisation by paying a small membership fee and then personally arranging their stay at a WWOOF farm by contacting the host they wish to visit. During a stay on a WWOOF farm, accommodation and food are provided for visitors in exchange for volunteer work on the farm property (McIntosh \& Campbell, 2001). Visitors are expected to become fully immersed in the day-to-day activities of their hosts and to receive a 'hands-on' experience of organic growing methods (Strange \& Strange, 2001). Activities at a WWOOF farm as part of the exchange vary depending on the WWOOF host and type of farm, but usually include general farm and garden duties. WWOOFing can therefore be seen both as an 'accommodation' and an 'activity' based form of farm tourism (Davies \& Gilbert, 1992).

\section{Dimensions of the Farm Stay Experience}

Two factors may potentially differentiate the nature of the home stay experience on a WWOOF farm compared to other farm stays, namely, the volunteer and exchange nature of the stay, and the organic philosophies and practices of the farm hosts. Indeed, McIntosh and Campbell (2001) concluded that the nature of WWOOF farms and their management were somewhat different from other farm tourism enterprises, especially in terms of hosts' motivations and values. Specifically, McIntosh and Campbell (2001:125) found that WWOOF hosts were, 'environmentally-minded, possessed environmentally-based values, displayed environmental concern and reported following sound environmental practices'. The main experiences that WWOOF hosts wanted to offer included the opportunity to experience an alternative lifestyle, education, learning about organics and the opportunity to stay with 'real' New Zealanders. However, the extent to which hosts and visitors on WWOOF farms share an exchange of culture and organic farming philosophy remains unexplored.

An increasing number of studies have examined the nature of the experiences provided for tourists at cultural and landscape attractions or boutique accommodation (see, for example, Beeho \& Prentice, 1997; McIntosh \& Siggs, 2005; Prentice et al., 1994, 1998; Schanzel \& McIntosh, 2000). These studies provide an understanding of how tourism encounters are personally meaningful to visitors and the unique benefits and satisfaction that can result from such encounters. Indeed, it is increasingly recognised that visitors to more specialised tourism products, including farm stays, are motivated by the personal and meaningful experiences available rather than any other consideration, including cost (Pearce, 1990). As such, a focus on visitors' experiences is important for evaluating the success of the visit, as well as for broader issues of product development, marketing and ultimately, the achievement of sustainable tourism. It also has important consequences for the success of farm hosting, particularly where the need to contribute to the organic movement is seen as potentially more important among farm hosts than the act of hosting (McIntosh \& Campbell, 2001). As Pearce (1990) has noted, 
even when guests visit voluntarily, there is no guarantee that their attitudes and understandings of the (organic) farming process will be affected. A lack of mutual understanding and values in host-guest interaction may lead to misunderstanding, confrontation or conflict between host and visitor, or to the host being less prepared to host visitors altogether. As such, research into hosts and visitors' perspectives of the farm stay experience is called for.

This paper seeks to provide descriptive insights into the nature of the WWOOF farm stay experience in New Zealand from the perspectives of both hosts and visitors. The study had two main aims. Firstly, as there is little information regarding WWOOFers, the study sought to examine the demographic profile of WWOOFers in New Zealand. Secondly, the study aimed to contribute to current knowledge about the farm stay experience by providing insights into the characteristics that are common to a hosted stay on a WWOOF farm and to investigate whether the experiences provided for WWOOFers are notably different from those offered by other farm hosts.

\section{Methodology}

To examine the demographic profile of WWOOFers in New Zealand, secondary data analysis of the membership records held by the New Zealand WWOOF organisation was undertaken. In total, 2231 application forms were analysed. This number represented the total number of applications received by the New Zealand WWOOF organisation between January and August 2001. It should be noted that the sample represented those people who gained WWOOF membership during this period and not necessarily those people who stayed on a WWOOF farm. It is very likely, however, that as visitors are required to gain WWOOF membership before they can stay on a WWOOF farm, the majority of applicants who paid their membership fee will have visited at least one WWOOF farm. Quantitative research is called for to provide baseline data on visitors staying at WWOOF farms to substantiate the profile of the WWOOF applicants reported here.

Data from the application forms were coded into numerical form and analysed using the Statistical Program of the Social Sciences (SPSS). Descriptive analysis of the data revealed the demographic profile of WWOOFers and their reasons for joining the WWOOF organisation. Due to four differing formats of the application forms (that is, internet, mail or fax, agency and direct letter), consistent information could not always be gained from the forms. For example, the internet application form was the only format that asked for an applicant's age, intended length of stay in New Zealand and previous WWOOF experience and this form was used by $30.6 \%$ of respondents. Many forms had not been fully completed and a high number of missing values were evident from the analysis of data. In the interpretation of the data, comparisons were drawn, where data existed, with the general profile of commercial farm stay visitors in New Zealand, as well as other visitor types (details are given later in the paper).

To explore the nature and dimensions of the WWOOF farm stay experience, a qualitative approach using in-depth conversational style interviews was deemed appropriate. This approach was similarly used by Pearce (1990) in his study of the social interaction between hosts and visitors within the farm stay context, although his study only included conversational interviews with hosts and not 
visitors. Other previous farm tourism studies have predominantly adopted quantitative approaches in their search for generalisation (e.g. Oppermann, 1996; Warren \& Taylor, 1999). Qualitative research methods have been advocated as a more effective way to understand experiential phenomena (Lofland \& Lofland, 1995; Patton, 1990), and have increasingly been applied to understand the nature of the tourism experience (see e.g. Beeho \& Prentice, 1997; Schanzel \& McIntosh, 2000). A particular benefit of adopting a qualitative approach is that dimensions of the tourism experience can be derived through inductive analysis using respondent's own descriptions, thereby enhancing the reliability and validity of the research.

Adopting a case study approach, in-depth interviews were conducted with 22 WWOOFers (visitors) and 12 WWOOF hosts. The sampling and case study approach are consistent with previous studies of the visitor experience (e.g. Beeho \& Prentice, 1997; McIntosh \& Siggs, 2005; Thyne, 2001). The interviews were undertaken at 12 WWOOF farms in the Canterbury region of the south island of New Zealand during the autumn season of 2001. The Canterbury region was selected for its prominence as both a tourist region and its high concentration of agricultural activity. A total number of 7710 farms were recorded for the Canterbury region in 2002 (www.maf.govt.nz/statistics/primaryindustries/ land-use-and-farm-counts/tables / 02-ft.rc.xls), representing approximately 15\% of the total number of farms in New Zealand. Canterbury also has a relatively high proportion of WWOOF farms ( $N=75$, or, $12 \%$ of all WWOOF farms in New Zealand). The case study region was quota sampled, that is, WWOOF farms were randomly selected within each of the region's six geographical sub-regions, and the number of farms sampled in each sub-region was proportionate to the total number of WWOOF farms listed for the Canterbury region overall.

Of an initial 56 randomly selected farms in Canterbury, 12 farms were able to be included in the study. The 12 farms were generally representative of the profile of WWOOF farms in Canterbury, that is, they were mainly small 'life-style blocks' or 'hobby farms' rather than commercially viable organic farms. The majority of non-respondents reported that they did not have any visitors staying $(N=33)$ as the study was conducted during the off-peak tourist season. Time constraints and lack of availability to participate due to other farm or business commitments represented the main reasons why other WWOOF farms declined to participate in the study. At the 12 farms selected, the host who reported that they had most contact with the visitors (usually the female partner) was interviewed.

All visitors staying at the farm who were willing to participate were interviewed. At three of the selected WWOOF farms, one visitor was interviewed at each farm, at eight farms two were interviewed at each farm, and at one farm three visitors were interviewed. Each interview was conducted in a private area at each farm with nobody else around. This aimed to ensure the ease and validity of responses from the interviewees, and to ensure that insights were gained into the nature of the WWOOF experience in its naturally occurring situation or setting (Lofland \& Lofland, 1995). The interviews were tape-recorded and later transcribed to ensure the accuracy of data. Because of the qualitative nature of the research, English-speaking visitors only were interviewed. WWOOF farms were contacted first by mail and then later by telephone to arrange interview times. 
Only visitors who had at least one week of WWOOF experience and had been present on the farm for at least three nights were selected for interview. This ensured that respondents had enough time to gain some degree of WWOOF experience.

A semi-structured interview schedule employing the principles of the 'laddering technique' (see Reynolds \& Gutman, 1988) was used to elicit respondents' experiences as expressed by them in their own words. The laddering technique is an attempt to link concrete reasons for undertaking an activity with more intrinsic reasons. It aims to achieve this by using probing questions such as 'Why is that important to you?' The method aims to achieve a context specific and inductive profile of an individual's thoughts and valued experiences. The interview schedule did not include a fixed list of questions that must be asked in particular words, but a list of themes to be covered in a conversational style interview. Conversational style interviews are considered an effective method for eliciting honest, natural and detailed perspectives from interviewees in a hosted accommodation context (see Pearce, 1990). Drawing on themes used in previous studies of the tourism experience, the interviews conducted with visitors on the WWOOF farms included themes relating to their motivations, values, experiences and activities, highlights of the stay, difficulties and the benefits they gained. The interviews conducted with WWOOF hosts included themes relating to their motivations for hosting, the value of being a WWOOF host, the positive and negative experiences of hosting and what experience(s) they wanted to provide for visitors.

Analysis of the in-depth interview transcripts with visitors and their WWOOF hosts involved the search for common themes evident from the data (Patton, 1990). In interpretation of the findings, it was important to review published literature to be able to provide some comparative comments with previous farm stay research in New Zealand. However, the findings of the qualitative research reported here should be considered indicative and exploratory rather than substantive. Further quantitative research could usefully validate the dimensions of the WWOOF farm stay experience reported here and seek to examine how market segments may experience organic and commercial farm stays differently.

\section{Profile of WWOOFers in New Zealand}

An analysis of 2231 WWOOF application forms received by the New Zealand WWOOF organisation between January and August 2001 revealed the demographic profile of visitors applying to stay on a WWOOF farm in New Zealand (see Table 1). The majority (93.5\%) of applicants were international visitors, with the largest proportions of applicants from Europe (52.2\%), North America $(22.4 \%)$ and East Asia (12.7\%). Applicants predominantly originated from the following four countries: the USA (17.9\%), Germany (17.6\%), the United Kingdom (17.2\%) and Japan (10.2\%). There is evidence to suggest that this visitor profile is in contrast to that reported for commercial farm stays and rural tourism enterprises in New Zealand where a predominance of domestic visitors has been reported (see Warren \& Taylor, 1999).

The mean average age of applicants was 26.7 years. The age of WWOOF applicants was found to be younger than that reported in previous farm tourism research in New Zealand. Warren and Taylor (1999), for instance, reported that 
Table 1 Summary Profile of WWOOF applicants

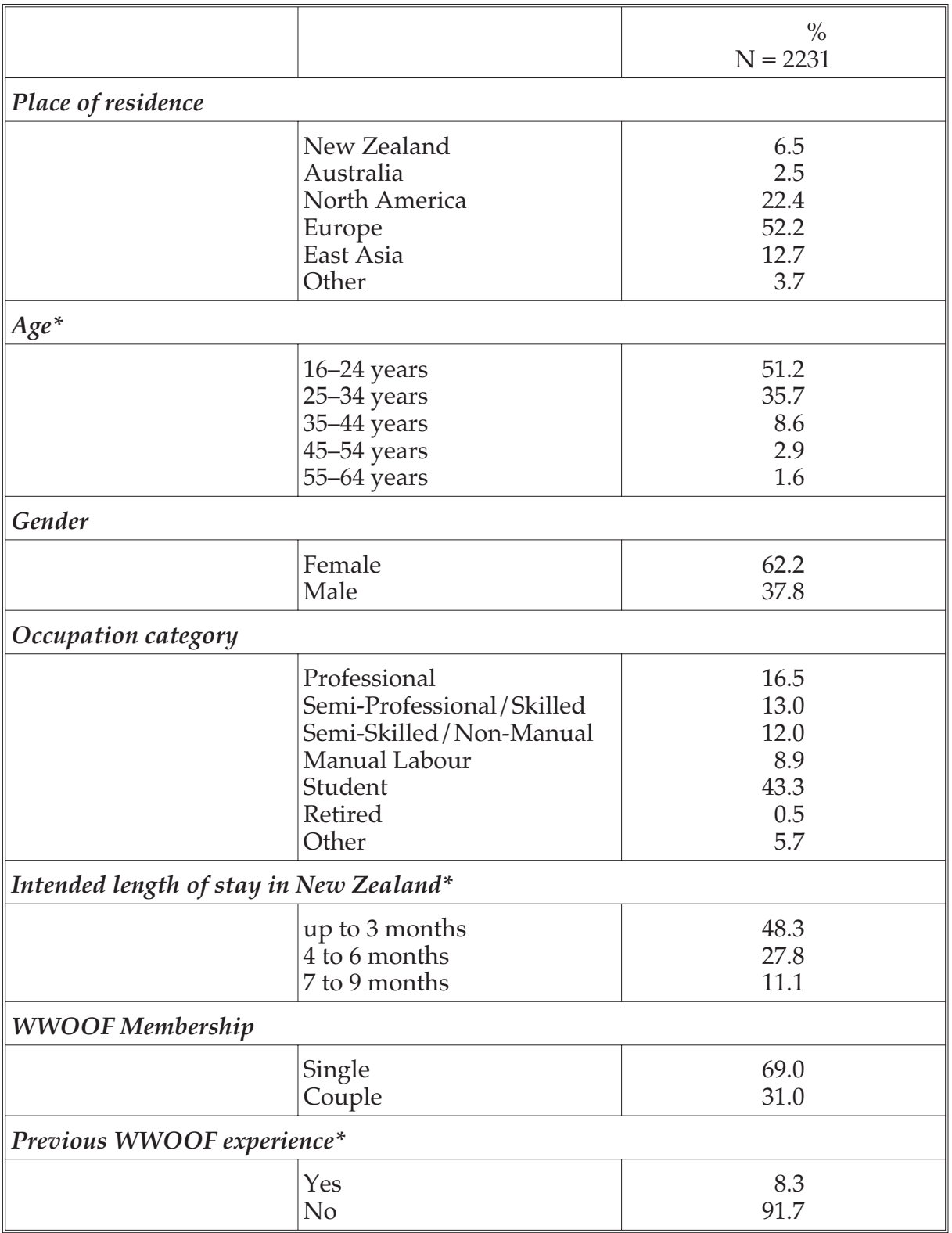

* Note: Data could only be obtained from on-line applications, therefore, $N=684$

most tourists who visit rural tourism enterprises in New Zealand are aged between 40 and 59 years. The younger age profile of WWOOFers appears to be more similar to the age profile of backpackers in New Zealand (Moran, 1999). In particular, younger visitors may be more interested in socio-cultural learning experiences, be more willing to work as a volunteer and may stay longer than older visitors. Indeed, more than half $(51.2 \%)$ of the applicants intended to stay in 
New Zealand for more than three months. A longer duration of stay has been reported among long-term budget travellers (Riley, 1988) and backpackers (Loker-Murphy \& Pearce, 1995), but this finding is not consistent with the profile of visitors to commercial farm stays in New Zealand. Warren and Taylor (1999), for instance, reported that $88 \%$ of visitors staying with rural tourism operators in New Zealand in 1996 stayed an average number of fewer than three nights.

In addition, the majority (62.2\%) of the WWOOF applicants were female. The gender bias was found to be less common among visitors staying at commercial farm stays and among international visitors to New Zealand generally (Statistics New Zealand, 2001; Warren \& Taylor, 1999). Potentially, women may be more likely than men to undertake volunteer work and stay with a host family when travelling in New Zealand. Indeed, Riley (1988) found that among long-term budget travellers, women were more likely than men to need company and 'nurturing' when travelling alone. In terms of occupation, $43.3 \%$ of the applicants were students and $29.5 \%$ of the applicants were employed in either professional or semi-professional occupations (see Table 1). This finding was also similar to the profile of backpackers (Loker-Murphy \& Pearce, 1995; Moran, 1999; Toxward, 2000). As such, WWOOFers may share more similar demographic characteristics with the profile of long-term budget travellers, such as backpackers, than the profile of commercial farm stay visitors. The extent to which this finding is country or destination-specific, however, requires further investigation.

The intended travel behaviour of the applicants provided further support for this conclusion. Consistent with the travel behaviour of backpackers and long-term budget travellers (see Loker-Murphy \& Pearce, 1995; Riley, 1988), a majority $(69.0 \%)$ of the applicants reported that they intended to go WWOOFing alone. In contrast, previous visitor research at commercial farm stays in New Zealand showed that most guests travel as part of a couple or as a family (Oppermann, 1998; Warren \& Taylor, 1999). Almost all the applicants $(91.7 \%)$ had no previous WWOOF experience in New Zealand or overseas. Reasons for joining WWOOF New Zealand included an interest in learning about organic farming $(40.5 \%)$, to meet and stay with local New Zealanders and experience their everyday life (32.0\%), to travel around New Zealand (31.1\%), to experience farm life $(15.7 \%)$ and to experience an alternative lifestyle (11.2\%). Other reasons included to work outdoors, do volunteer work, gain life experience, learn English, save money and give something back to the land. As such, the reasons for joining the WWOOF organisation were predominantly socio-cultural and educational in nature. However, while the largest proportion $(40.5 \%)$ of applicants stated that their reason for joining WWOOF was to learn about organic farming, this was not a reason stated by the clear majority of applicants. As the philosophy of organic farming is a key aspect of the WWOOF scheme, this may have potential impacts on the nature of the experiences gained by visitors staying on a WWOOF farm if the majority of visitors do not share the same interests and values as their hosts.

\section{The Nature and Characteristics of the WWOOF Farm Stay Experience}

A brief description of the WWOOF hosts and farm properties in the context of the present study is important to establish the nature and characteristics of the 
hosted experience being provided. In terms of demographic profile, the WWOOF hosts interviewed in the present study were found to be similar to the profile of farm stay hosts reported elsewhere in New Zealand (Hogh, 2001; McIntosh \& Campbell, 2001). That is, the majority of the WWOOF hosts interviewed were females, aged between 40 and 59 years, with half of the hosts interviewed having dependent children living at home. However, caution should be given in generalising from this comparison with the profile of other farm hosts as the comparative studies were similarly case studies based on small sample sizes. Most of the WWOOF farms visited in the present study were small properties with small-scale ventures, 'hobby farms' or 'lifestyle blocks' where organic farming and gardening principles were applied. However, only onethird (four out of 12) of the WWOOF farms visited were engaged in organic farming commercially and held an organic certification trademark. Unlike most commercial farm stays whose primary or secondary occupation is farming, the primary occupation of most WWOOF hosts was not farming, with most of the hosts interviewed having off-farm employment as a main source of income.

Some of the WWOOF hosts lived in an atypical design of house, for example, a self-built mud brick house, a remodelled barn or a bush hut; some had particular diets (for example, they only eat organic produce), others practised alternative healing techniques, used sustainable energies in the home, some had composting toilets or a long drop, others followed alternative or home schooling methods, or grew rare crops or kept alternative stock (for example lamas). The alternative lifestyles of the WWOOF hosts interviewed were found to be consistent with the profile of other WWOOF hosts listed in the New Zealand WWOOF book in 2002, as well as the perception of those WWOOFers interviewed who had had previous experience of visiting WWOOF farms in New Zealand. The lifestyle experienced by WWOOF hosts may therefore be different from commercial farm stay hosts and hence they, potentially, do not represent a 'typical' New Zealand farm family as described in the published literature on farm stays (Hogh, 2001; Pearce, 1990).

The profile of the visitors interviewed at the WWOOF farms was found to be consistent with the profile of the WWOOF applicants discussed above. When asked about their motives for travel, many interviewees expressed the need for 'a break away from normal life', the 'wish to explore the world' and the 'search for something different'. As such, sightseeing and engaging in other tourist activities were as much an integral part of their trip to New Zealand as the opportunity to stay on a WWOOF farm. Findings of the in-depth interviews with visitors showed that the quality of the accommodation provided at the WWOOF farms was varied. However, overall, most interviewees reported being satisfied with the accommodation offered to them. The nature of the work and free-time activities undertaken and length of time worked by respondents also varied, depending on the host's expectations, what type of help was required on each property, the skills and willingness of the visitors, the season and weather conditions. Interviewees reported that they typically worked for between four and six hours a day. The tasks that visitors had been engaged in included general farm and garden work such as planting, weeding, harvesting or feeding animals and building work as well as household duties and child minding. 
A few visitors interviewed complained about the number of hours' work expected, sometimes feeling that they had been taken advantage of. Likewise, some hosts felt the same. For example, comments made by the WWOOF hosts interviewed included, 'We are a bit concerned that people are using WWOOFers as slave labour, like commercial places that advertise for WWOOFers. It does not seem right to us'; 'If they only want to come for a few days, they don't really want to work or learn something, they just want to use the WWOOF system as a cheap way for holidaying'. In contrast to staying on a WWOOF farm, visitors to commercial farm stays may not experience this conflict over their role in farm duties. Indeed, helping with farm work has been found to be of low appeal for many visitors to commercial farms in New Zealand. Commercial farm stay visitors are primarily attracted by scenic beauty, proximity to tourist routes and attractions as well as passive farm activities such as observing stock and farm activities (Pearce, 1990; Warren \& Taylor, 1999). An individual WWOOFer's willingness to work long hours may be dependent upon the perceived value of the experiences they gain and their respect for their hosts. For instance, one WWOOFer explained that, 'So as long as I felt like the people who own the property were worth working hard for, then I would do just about anything. I would not wear a watch or anything, I would just work and enjoy it'. Only a few areas of other potential conflict were noted and these were found to be similar to those identified for commercial farm stays in New Zealand (see Pearce, 1990). The areas of potential conflict between host and visitor on the WWOOF farm included differences in eating habits, language difficulties, witnessing arguments among host family members and lack of privacy for hosts and visitors.

The differences noted in the characteristics of a stay on a WWOOF farm compared to a commercial farm rendered the nature of the experiences gained by visitors as potentially different. Four common dimensions of the WWOOF farm home stay experience were revealed from the in-depth interviews with visitors and hosts alike, namely, the rurality of the experience, the opportunity to learn about organics, the personal meaningfulness of the experience and the element of sincerity in the experience. These dimensions are elaborated below.

\section{The rurality of the experience}

Staying on a WWOOF farm was characterised by visitors and hosts as an experience of rural landscape and lifestyle. The overall rural nature of the experience included two predominant aspects, namely, the 'peacefulness' of staying in the countryside and 'participation in farm life and activities'. While an experience of the 'peacefulness' or the tranquillity of the rural environment has been similarly found in studies of the commercial farm stay experience in New Zealand (Pearce, 1990; Warren \& Taylor, 1999), the extent of participation by WWOOF visitors in rural lifestyle and farm activities was potentially different from that gained by commercial farm stay visitors, although this conclusion requires further substantiation. These two aspects are illustrated below using quotes from the visitors and hosts interviewed at the WWOOF farms.

As an illustration of the 'peacefulness' experienced by visitors on a WWOOF farm, one visitor described how, 'I had no idea about the impact that the scenery would have on me. It was totally different from what I expected; so peaceful. I stopped working in the garden and just stood looking at the stunning scenery'. 
Other comments made by visitors included, 'I can't believe that I' $m$ working in such an environment. I can see the sunshine, the sunlight, and sunset. I can see no pollution, no stress, very quiet, very relaxed'; 'I had got to the stage where I was really looking forward to getting out into the country, away from the city, away from everything; it's so peaceful here'.

An experience of farm life by being involved in the day-to-day farming activities was also evident as an element of the rural nature of the WWOOF farm stay experience. For example, visitors' comments included, 'I had never been on a farm before, so I thought it would be a totally new experience'; 'It was my dream to work on a farm. I grew up in a city where it's hard to stay on a farm; I wanted to grow vegetables and tend to sheep'; 'The most wonderful part of this experience, for me, was driving a tractor, doing milking, and making butter from the milk'. Tending to farm animals, in particular, was often reported to be an important component of the rural experience. For example, visitors described how, 'I love the animals, like feeding the cows'; 'There was a baby sheep born last night, that I got to witness; I had never experienced anything so exciting'. Similarly, one WWOOF host commented that, 'I remember, one girl came from a commercial farmstay ... and coming here was an eye-opener to her. There [at a commercial farmstay] you are getting in touch with nature to an extent, but here, people get involved, they get their body in, and that makes the difference'. Participation in farm activities was thus potentially far more active among visitors to the WWOOF farms than that reported for commercial farm stays.

\section{The opportunity to learn about organics and alternative lifestyles}

Staying on the WWOOF farms was found to be potentially different from that reported at commercial farm stays as the farm life and work experienced offered the opportunity for WWOOFers to learn about organic growing and farming methods and alternative lifestyles. While approximately half of the visitors interviewed reported a primary interest in learning about organics during their stay, it was found to be a much more prominent part of the experience gained by almost all the visitors interviewed. Indeed, comments made by visitors described how, 'In the beginning, I had no motivation at all to know more about organic farming to be honest, just that it was a thing I could do that was totally different and that always appeals' and, 'Doing WWOOFing, you get a different idea about what gardening is about. I had never met people who had an organic farm or a self-sufficient place as a lifestyle, as the people have it here. These places have a lot to offer in terms of things I could learn. I now want to grow my own food and learn more about organic farming; that would never have entered my head if I had not gone WWOOFing'. Other visitors described how, 'I have learned a lot about bio-dynamics, about permaculture and about sustainable lifestyles. I have learned a lot about seeds, seed collection and how long they last. And about different ways of fertilising, like compost or fish fertiliser, or comfrey fertiliser'; 'I have learned organic details, like I learned to differentiate between different hazelnut varieties; strange things that I have no use for at home'; 'I don't think I even knew what organics was when I started here'; 'We are pretty much converted to organics now, that if we have the opportunity to grow our own vegetables, we will absolutely be organic'; 'But it's not just about organic farming and gardening; it is a lifestyle, alternative healing, massage, mediation, 
alternative energy, a whole spectrum of things; that's really interesting to learn about'. In this way, the nature of the experience of staying on a WWOOF farm has an educational aspect specifically related to learning about organics and alternative lifestyles. In contrast, long-term budget travellers or working tourists have not usually been found to take jobs that provide such level of training or knowledge base (see e.g. Pizam et al., 2000; Riley, 1988; Uriely \& Reichel, 2000).

The research provided some evidence, therefore, to suggest that while interest in organics may not be a primary motivating factor among the majority of visitors at WWOOF farms, the environmentally based or alternative lifestyle values held by WWOOF hosts may in fact be reflected in the nature of the experiences shared with visitors. For example, the WWOOF hosts interviewed generally commented that while they recognised that the majority of visitors were not primarily interested in organics, it was an important part of the daily routine at the WWOOF farm. This varied, however, depending on the level of commitment to organic farming practised by the WWOOF farms. As one host described, 'I used to try to tell them a little about organics, but over the years I've found that they could not care less about organics really; the majority of them are here to just experience a bit of Kiwi people and living, and unless they ask me, I wouldn't say much about organics, because you don't get anywhere by trying to force things on anybody. But just being part of the day here, they have to think organically somehow'. Other comments made by hosts included, 'Most of the WWOOFers aren't really interested in organics. But I make sure that they want to get their hands dirty'; 'I suppose out of thirty we'd have about six that are really interested in organics, or interested in learning anything about the gardens'; 'I teach them a lot, from very basic things like showing them the compost, showing them the worms. They are learning to catch possums. The advanced people can learn much more, just look here at all those books and magazines on organics, on permaculture, on forests, on possums'.

\section{The personal meaningfulness of the experience}

The research revealed that visitors staying on the WWOOF farms reported personal meaningfulness or self-reflection from the experiences they had gained. The personally meaningful nature of the experiences gained related to the involvement of the visitor in a voluntary working-holiday experience which provided the opportunity to take 'time to think', get 'close to nature', 'watch', to 'compare one's own lifestyle' with the lifestyle of people who, predominantly, are living an unconventional lifestyle, and to assess what is personally meaningful to them. In particular, these benefits may have been meaningful to visitors as many of them reported being at a junction in life (for example, taking time to travel after completing a university degree) and, hence, looking for a future direction. For almost all of the younger visitors interviewed, WWOOFing was an opportunity to achieve this while saving money, although these visitors described how the personal meaning they derived was more important to them than having a budget stay. In terms of the nature of the experiences gained therefore, visitors staying on WWOOF farms may be motivated for different reasons compared to tourists choosing other budget accommodation types, such as backpackers (Loker-Murphy \& Pearce, 1995). Similar to other types of volunteer tourists (see e.g. Pizam et al., 2000; Uriely \& Reichel, 2000), the research findings 
provided some evidence to suggest that visitors staying on WWOOF farms do not only work to travel, but they appear to give additional meaning to their work activity, although this conclusion requires further substantiation.

In relation to the personal meaningfulness of the experience, visitors described how, 'I think WWOOFing has encouraged me for personal growth'; 'It inspired me to be here; to see that the little tiny ideals I had, like taking care for the environment and doing things by and for myself, are practised here'; 'The ability and openness to search within myself, which was another reason for coming on this trip, to see who I am a little bit more, understand myself a bit more, make comparisons with the people around you and see where they are heading and where you're heading, and where you want to be heading; I feel like these people are providing me with that opportunity'.

The visitors interviewed, in particular, described how working outdoors, getting physical exercise and feeling 'in contact with nature' was a prominent part of the experience they had found to be personally meaningful. Interviewees commented on how, for example, 'I have always liked to be outside. I find it very calming, very soothing and peaceful; it makes me feel good'; 'You get something to do on the farm, your muscles work again, your brain works again, it's like growing again'; 'If you work outside, you feel on your body every drop of temperature, every drop of rain, every bit of sun and wind; you are just in the middle of it and I just like it; that's why I'm here'. As such, there was some evidence to suggest that the experience of staying on a WWOOF farm provided respondents with an experience of 'rootedness' and 'being in touch with nature' that they felt they had lost in their life at home. Indeed, visitors described how, 'You get dirty which you don't get working in an office; it brings you in contact with the earth and makes you feel a bit more real I suppose'; 'I like dirty hands, the smell of soil and stuff like that because its simple and natural'; 'It's all about reconnecting your soul with the earth'; 'it's an experience of the fascination of taking care of whatever nature provides'; 'It's about contributing; I look at it as more than just an exchange and trade food for work though. This experience is helping me in so many ways to broaden myself, and so I am helping them; I also want to give something back to the land'. As such, the experience of working outdoors and feeling close to nature gave respondents a feeling of being useful, of personal achievement and of personal meaning that had not been apparent in their everyday lives or travelling.

The personal meaningfulness of the WWOOF experience was similarly reported by the hosts interviewed. Hosts' comments included, 'Many WWOOFers are still at an age where they are trying to figure out how they are going to get satisfaction out of their life. They see that I live my work, they see that you can be whomever you want to be in New Zealand. It sounds like shit over there, too many people too many rules, both in Japan and Europe. This here helps them to realise what it is they want to do everyday'; 'I realised that so many travellers are working out things about their lives, when they stay long enough that they can get into the peace of this place, they make dreams and so on. I have seen people go back and build new farms and new projects of all kinds; many Japanese girls are afraid of the future, they are afraid of becoming lonely women with their man away all the time in their small apartment somewhere and they are desperately looking for alternative dreams. For them, to dare to dream, that is the other side of the moon. 
Like one Japanese girl said to me, she has the dream to come back here and learn how to build violins from the guy down the road'.

\section{The element of sincerity in the experience}

Visitors' desire to meet and interact with local people has been widely discussed in the published literature and has been found to be one of the key motivating factors for commercial farm tourism in New Zealand (Pearce, 1990). While interaction with local New Zealanders was a key motivation among visitors to the WWOOF farms and a key dimension of the experiences gained, the findings of the in-depth interviews suggested that the socio-cultural nature of the experiences gained by visitors staying on the WWOOF farms potentially differed to those provided by commercial farms. Specifically, the research findings provided some evidence to suggest that because of the longer length of stay of most visitors on WWOOF farms compared to commercial farm stays, as noted above, and the fact that the WWOOF experience is a voluntary non-commercial barter system, the relationship between host and visitor was potentially more intense in nature and perceived as more meaningful and sincere. Indeed, in many other tourism settings, interactions between visitors and local people are argued to be transitory and thus, likely to be shallow and superficial (Sharpley, 1999).

The element of sincerity in the WWOOF experience was described by visitors as, 'I don't really enjoy travelling where you just go and have a look at a place and say, "Well, I've seen that"; I wanted to meet the people and hear their views on living in an area'; 'I have spent time with these people and got a feel for the country, and who lives there and why they live there and how they live there. To me, that is more gratifying. Not that seeing something isn't good, but experiencing something is much better because you take something to heart; as far as I am concerned, it takes a face, a personality, a brain and closeness with other humans and discussion with them, eating with them and working on their schedule in order to make an experience'; 'The experience is more dear to you because you get to know them'; 'We are treated as a member of the family. I think the most important thing is the kindness'; 'As I am travelling by myself, I avoid places where I don't get involved in family life'; 'Once you are considered a good friend instead of just someone passing through, then confidence is opened up and you get to know each other a lot better'. The chance to feel 'one of them', according to MacCannell (1976) means being permitted to see behind the others' mere performances and is an important aspect of an authentic experience. In this way, the potential for intense friendships and understandings to develop from the non-commercial experience of staying on a WWOOF farm may be more appropriately termed an experience of 'sincerity' (Taylor, 2001). This may also serve to heighten a visitor's emotional attachment or endearment to rural destinations they have visited, potentially more so than from a visit to a commercial farm stay.

The desire for sincere interaction was similarly described by the WWOOF hosts. Hosts' comments included, 'I'm a long stay host. I value forming a good relationship with the people. I won't take short stay people. They have to be here for two or three weeks at least, because I can't stand the house being like a railway station, it's exhausting. The short stay ones, they don't have the right spirit. They 
are treating the place like a backpackers and I don't feel regarded as a person, for me or our dreams, or our house, or anything'; 'I form close friendships with many WWOOFers; I do get photographs when they have their babies or when they get married. Some have come back here, like one Japanese guy and his wife are now coming to my son's wedding, all the way from Japan'; 'I have got some really good friends who live in Wellington and I first got to know them as WWOOFers here, when they came to our place. They come back now as friends, not as WWOOFers'; 'With commercial farm stay guests it's totally different. You have to be their servant as they are paying you money to stay here. I'd have to put my day aside to amuse them. I'd have to get formal. The WWOOFers, they've got to muck in'; 'I have done a little bit of B\&B in the past and when you are doing a farmstay you are putting on a show for people that have paid you money to be in your home. With WWOOFers that's the difference, they are staying, but as members of the household. You feed them well, you look after them well, but you don't run around after them. I don't do B\&B anymore because I really hated having everything spotless and perfect'; 'Sometimes WWOOFing is the only experience that they really hold dear, because they have seen real people not tourism operators. They travel around, they want to go off for their bungy jump and their jet boat ride, but this is more dear to them, because you get under their skin, you get to know people'.

\section{Conclusion}

Increasingly, hosting on organic (WWOOF) farms has become an important part of farm tourism (McIntosh \& Campbell, 2001). This is evidenced in the last decade by the increasing number of WWOOF farms that host visitors within rural regions. Findings relating to the profile of people who apply to visit WWOOF farms in New Zealand and an exploratory analysis of the nature of the WWOOF experience in a case study region in the south island of New Zealand have provided some evidence to suggest that the nature of staying on a WWOOF farm is potentially different from a hosted stay at a conventional commercial farm enterprise in New Zealand, although this requires further substantiation. Specifically, the demographic profile and travel characteristics of visitors to WWOOF farms were found to have greater similarity with that reported for backpackers and long-term budget travellers than commercial farm stay visitors. The nature of the experience provided for visitors at WWOOF farms was found to be different from other types of farms in New Zealand in that WWOOF hosts have different motives for hosting visitors and are more environmentally minded (see McIntosh \& Campbell, 2001). Furthermore, the farm properties are predominantly small lifestyle farms that may apply organic growing principles or encompass an alternative or self-sufficient lifestyle. As such, the type of food and accommodation offered at WWOOF farms varies.

The characteristics of a stay on a WWOOF farm were also notably different from commercial farm stays in other ways. In particular, visits to a WWOOF farm can only be self-arranged, visits are not commercial in nature and do not involve a monetary transaction, visitors typically stay for a longer period of time, living space and household duties are typically shared between host and visitor and visitors undertake voluntary work for approximately four to six hours of manual 
work on the host's property. Consequently, the nature of the experiences gained by visitors at the WWOOF farms was also somewhat different from the commercial farm stay experience. This paper has shown that the WWOOF farm stay experience can be described by four common dimensions; that is, the rurality of the experience, the opportunity to learn about organics, the personal meaningfulness of the experience and the element of sincerity in the experience.

As is the case with commercial farm stays, the experience of staying on a WWOOF farm involves personal interaction with hosts in their own home environment and experience of a rural or farming lifestyle, with potentially greater participation in farm activities. In the main, demand for farm stay experiences may be a result of travellers' desires to escape commercial accommodation in search of more sincere and meaningful experiences in a rural setting. Conventional farm stays could be argued to turn country friendliness and farm life into a commercial product (Pearce, 1990). Instead, the research presented here revealed the nature of the WWOOF experience to be potentially more intense, meaningful and 'sincere' than that provided by commercial farm stays. However, if the WWOOF organisation packaged WWOOF experiences in the same manner as other commercially marketed farm home stays and rural tourism experiences, the visitors who stay on a WWOOF farm may indeed increasingly represent a proportion of people wanting a 'free farm stay' or a 'romanticised' experience of farm life (Nilsson, 2002). However, more research is called for into the nature of demand for alternative farm stays to substantiate the conclusions drawn here. In particular, research that provides an analysis of whether any of the experience dimensions reported here were more prevalent among certain types of visitors, or differed across countries, would add further insight to current discourses.

Because of the philosophies of the WWOOF organisation and its network of member farms, the WWOOF experience may have the ability to heighten understanding between people from different cultural, social or ideological backgrounds, 'endear' visitors to rural regions in support of wider economic development initiatives, engender or raise appreciation, care and concern for the natural environment, support for the organic movement or an alternative lifestyle, and encourage self-reflection and personal development among visitors. Similar beneficial experiences have not been reported in the published literature on farm tourism to date and, as such, the nature of staying on a WWOOF farm may indeed constitute an alternative farm stay experience, although further research is called for to validate the exploratory conclusions drawn here. However, caution is advocated. As a majority of visitors staying at the WWOOF farms did not report a primary interest in organic principles, while the nature of the farm stay experience may be different conceptually from commercial farm stays, a stay on a WWOOF farm may not be as 'organic' in nature as the aims of the WWOOF organisation might imply. The nature of the WWOOF experience may therefore have undergone a shift, becoming more focused perhaps on alternative living and becoming increasingly viewed by visitors as a more sincere cultural travel experience. However, as the findings of this paper suggest, a stay on an organic farm does have the potential to engender an interest in organic farming principles and alternative lifestyles among those visitors who might not otherwise have been aware of environmental alternatives. 
Finally, the work of the WWOOF network and the findings of this research recalls some of the aims of the pioneers of the sustainable tourism paradigm in the 1980s (Krippendorf, 1987; Krippendorf et al., 1988). They hoped to encourage 'alternative tourism' that was more reflective and insightful. They sought to change the nature of the host-guest relationship, and they sought to encourage longer stays to reduce the environmental impacts of travel. Perhaps WWOOFing offers, in a small way, an approach towards those ideals.

\section{Acknowledgements}

The authors wish to thank Andrew and Jane Strange of WWOOF New Zealand for their support and contribution to this research, and the Environment, Society and Design Division, Lincoln University for funding the project. An earlier version of this research was presented at the ATLAS Annual Conference in Naples, Italy, in April 2004.

\section{Correspondence}

Any correspondence should be directed to Dr Alison McIntosh, Department of Tourism Management, The University of Waikato, Private Bag 3105, Hamilton, New Zealand (mcintosh@waikato.ac.nz).

\section{References}

Beeho, A.J. and Prentice, R.C. (1997) Conceptualizing the experiences of heritage tourists: A case study of New Lanark World Heritage Village. Tourism Management 18 (2), 75-87.

Davies, E.T. and Gilbert, D.C. (1992) A case study of the development of farm tourism in Wales. Tourism Management 13 (1), 56-63.

Hogh, L. (2001) Farming the tourist: The social benefits of farm tourism in Southland, New Zealand. Pacific Tourism Review 4 (4), 171-7.

Krippendorf, J. (1987) The Holidaymakers. London: Heinemann.

Krippendorf, J., Zimmer, P. and Glauber, H. (1988) Fuer einen andern Tourismus [Towards an alternative tourism]. Frankfurt am Main: Fischer Taschenbuch.

Lofland, J. and Lofland, L.H. (1995) Analysing Social Settings: A Guide to Qualitative Observation and Analysis (3rd edn). Belmont, CA: Wadsworth.

Loker-Murphy, L. and Pearce, P.L. (1995) Young budget travellers: Backpackers in Australia. Annals of Tourism Research 22 (4), 819-43.

MacCannell, D. (1976) The Tourist: A New Theory of the Leisure Class. New York: Shocken.

MacCannell, D. (1992) Empty Meeting Grounds: The Tourist Papers. London: Routledge.

McIntosh, A. and Campbell, T. (2001) Willing Workers on Organic Farms (WWOOF): A neglected aspect of farm tourism in New Zealand. Journal of Sustainable Tourism 9 (2), 111-27.

McIntosh, A.J. and Siggs, A. (2005) An exploration of the experiential nature of boutique accommodation. Journal of Travel Research 44 (1), 74-81.

McKenzie, G. (1994) Farm based accommodation: An investigation into the motivation, expectation and satisfaction of farm hosted visitors in Southland. Unpublished MA Thesis, University of Otago, Dunedin, New Zealand.

Moran, D.M. (1999) Interpreting tourism experiences: The case of structured backpacker tours in New Zealand. Unpublished PhD Thesis, Lincoln University, New Zealand.

Nilsson, A.P. (2002) Staying on farms: An ideological background. Annals of Tourism Research 29 (1), 7-24.

Oppermann, M. (1996) Rural tourism in southern Germany. Annals of Tourism Research 23 (1), 86-102.

Oppermann, M. (1998) Farm tourism in New Zealand. In R. Butler, C.M. Hall and J.M. Jenkins (eds) Tourism and Recreation in Rural Areas (pp. 225-33). Chichester: Wiley.

Patton, M.Q. (1990) Qualitative Evaluation and Research Methods (2nd edn). London: Sage. 
Pearce, P.L. (1990) Farm tourism in New Zealand: A social situation analysis. Annals of Tourism Research 17, 337-52.

Pizam, A., Uriely, N. and Reichel, A. (2000) The intensity of tourist-host social relationship and its effects on satisfaction and change of attitudes: The case of working tourists in Israel. Tourism Management 21, 395-406.

Prentice, R.C., Witt, S.F. and Wydenbach, E.G. (1994) The endearment behaviour of tourists through their interaction with the host community. Tourism Management 15 (2), 11725.

Prentice, R.C., Witt, S.F. and Hamer, C. (1998) Tourism as experience - the case of heritage parks. Annals of Tourism Research 25 (1), 1-24.

Reynolds, T. and Gutman, J. (1988) Laddering theory, method, analysis and interpretation. Journal of Advertising Research 28 (1), 11-31.

Riley, P.J. (1988) Road culture of international long-travel budget travellers. Annals of Tourism Research 15, 313-28.

Schanzel, H.A. and McIntosh, A.J. (2000) An insight into the personal and emotive context of wildlife viewing at the Penguin Place, Otago Peninsula, New Zealand. Journal of Sustainable Tourism 8 (1), 36-53.

Sharpley, R. (1999) Tourism, Tourists and Society (2nd edn). Huntingdon: ELM.

Statistics New Zealand (2001) International Visitor Arrivals to New Zealand - May 2001. Wellington.

Strange, A. and Strange, J. (2001) WWOOF New Zealand - Living and Learning the Organic Way. Nelson: Willing Workers on Organic Farms New Zealand.

Taylor, J. (2001) Authenticity and sincerity in tourism. Annals of Tourism Research 28 (1), 7 26.

Thyne, M. (2001) The importance of values research for non-profit organisations: The values based motivations of museum visitors. International Journal of Nonprofit and Voluntary Sector Marketing 6, 116-30.

Toxward, S.J. (2000) Backpacker's expectations and satisfactions - a case study of Northland, New Zealand. Unpublished MA thesis, Lincoln University, New Zealand.

Uriely, N. and Reichel, A. (2000) Working tourists in Israel and their attitudes to hosts. Annals of Tourism Research 27 (2), 267-83.

Warren, J.A.N. and Taylor, C.N. (1999) Developing Rural Tourism in New Zealand. Wellington, New Zealand: Centre for Research, Evaluation and Social Assessment. 